\title{
Toward the Design of Highly Efficient, Readily Accessible Peptide N-caps for the Induction of Helical Conformations
}

\author{
Richard Mimna, ${ }^{1}$ Gabriele Tuchscherer, ${ }^{2}$ and Manfred Mutter ${ }^{2,3}$
}

(Accepted December 27, 2006; Online publication March 27, 2007)

\begin{abstract}
A series of novel peptide $\mathrm{N}$-caps was designed with an emphasis on ease of synthesis and an abundance of hydrogen bond acceptors. Different scaffolds based on sugars, cyclic hydrocarbons, and amino acids are developed with a variety of hydrogen bond acceptors including esters, carboxyls, amides and a sulfonic acid. The efficient use in solid-phase peptide synthesis was demonstrated by incorporating the N-caps to a resin-bound model peptide. Their differential helix nucleating power in aqueous buffer was determined by CD studies. Increases in peptide helicity to a significant extent are observed, leading to a discussion of Ncapping efficiency versus ease of synthesis. The potential of the elaborated N-caps for the reversal of $\beta$-sheet to $\alpha$-helix conformations in the context of fibrillogenesis is discussed.
\end{abstract}

KEY WORDS: N-caps; peptidomimetics; helix nucleation; switch-peptides; CD studies.

\section{INTRODUCTION}

The $\alpha$-helix is the most abundant secondary structure found in proteins, accounting for almost $30 \%$ of all residues (Barlow and Thornton, 1988) and playing crucial roles in many biological processes such as receptor binding (Beck-Sickinger and Jung, 1995, Motta et al., 1989), DNA binding (Ellenberger et al., 1992, Tuchscherer et al., 1998), hemolysis (Bernheimer and Rudy, 1986), antibody recognition (Mutter and Tuchscherer, 2000) and membrane transport. In principle, the bioactivity stemming from a helical region of a protein should be reproducible through the use of the smaller, isolated helical sequence itself. However, a

\footnotetext{
${ }^{1}$ Alnis Biosciences, 21 Davis Dr., RTP, NC, 27709, USA.

${ }^{2}$ Swiss Federal Institute of Technology Lausanne (EPFL), Institute of Chemical Sciences and Engineering (ISIC), Lausanne, CH-1015, Switzerland.

${ }^{3}$ Correspondence should be addressed to: Manfred Mutter, Swiss Federal Institute of Technology Lausanne (EPFL), Institute of Chemical Sciences and Engineering (ISIC), Lausanne, CH-1015, Switzerland. Tel.: +41-21-6939411; Fax: +41-21-6939355; e-mail: manfred.mutter@epfl.ch
}

peptide sequence that adopts a helix within a protein will usually exhibit little or no secondary structure when excised from the stabilizing short- and long-range interactions present in the parent protein.

As helical structures are often related to bioactive conformations, some groups have explored ways of stabilizing helical conformations by substituting more helicogenic residues and/or introducing Asp ${ }^{i}, \operatorname{Lys}^{i}+4$ lactam bridges. For example, it has been shown that the helical N-terminal fragment of parathyroid hormone PTH(1-11) can be made 3,500 times more potent by substituting more helicogenic amino acids at specific positions (Barazza et al., 2005). However, such techniques require modifications to the original, native sequence, sometimes at the expense of critical residues that are involved in bioactivity.

An alternative means of increasing helicity involves the use of peptidomimetics known as N-caps that provide surrogate, stabilizing $\mathrm{H}$-bond acceptors at the $\mathrm{N}$-terminus of a peptide (a $\mathrm{C}$-cap provides $\mathrm{H}$-bond donors at the C-terminus). Such Helix-capping motifs are specific patterns of hydrogen bonding and hydrophobic interactions that substitute for the lacking intrahelical $\mathrm{H}$-bonds provided by the adjacent 
helical turn to satisfy backbone $>\mathrm{N}-\mathrm{H}$ and $>\mathrm{C}=\mathrm{O}$ groups in the initial and final turns of the helix. Furthermore, the helix geometry interferes with solvent access to the amide groups at the $\mathrm{N}$-terminus leaving the shielded polar groups unsatisfied, destabilizing the molecule considerably. To overcome these constraints at helix ends, distinct conformational motifs are used that can provide intramolecular $\mathrm{H}$-bond partners and maintain the hydrophobic interaction (Aurora and Rose, 1998). In the search of N-caps for optimal Hbonding and charge interactions for enhancing the maximum helicity of isolated peptides in aqueous solution, the primary goal so far was the need for CD calibration standards in the form of short to mediumsized chains of defined length that approach $100 \%$ helicity calibrated from Ncap-corrected experimental helicities at $222 \mathrm{~nm}$, even though the mechanisms of helix capping stabilization are not fully understood yet and the upper limit on cap-induced helicity remains largely unexplored (Maison et al., 2001). While $\mathrm{N}$-caps have the advantage of not requiring substitutions to the core sequence of a helical peptide, to date, most of the reported $\mathrm{N}$-caps that have been demonstrated to increase helicity to a significant extent are synthetically very demanding (Müller et al., 1993). In the interest of designing novel $\mathrm{N}$-caps that are both potent helix nucleators and readily accessible for use in solid-phase (Merrifield, 1963, Stewart and Young, 1984), liquid-phase (Bayer and Mutter, 1972) and solution synthesis (Bodanszky, 1984), we report here on the synthesis and evaluation of a series of compounds so far unexplored as $\mathrm{N}$-caps.

\section{MATERIALS AND METHODS}

\section{General}

Solvents and reagents were purchased from Fluka or Aldrich, Buchs, Switzerland and unless stated otherwise, were used without further purification. Fmoc amino acid derivatives and Rink amide resin were purchased from Novabiochem AG, Läufelfingen, Switzerland. Alloc protected amino acids were obtained from Isochem, Vert-le-Petit, France. All amino acid derivatives were used without further purification.

ESI mass analyses were recorded on a Finnigan MAT SSQ 710C electrospray spectrometer. All ${ }^{1} \mathrm{H}$ and ${ }^{13} \mathrm{C}$ NMR spectra were recorded on a DRX400 Bruker spectrometer at $30^{\circ} \mathrm{C}$. Chemical shifts are reported in ppm downfield from TMS. CD spectra were recorded on a Jasco J-810 spectropolarimeter with an integration time of $2 \mathrm{~s}$ for $0.2 \mathrm{~nm}$ steps using an average of five scans to obtain each spectrum. All CD spectra were recorded at a peptide concentration of $10 \mu \mathrm{M}$ in $10 \mathrm{mM}$ phosphate buffer at $0{ }^{\circ} \mathrm{C}$ and $\mathrm{pH} 7$ in quartz cells of $1 \mathrm{~mm}$ path length. Peptide concentrations were extrapolated from measurements of UV absorbance at $280 \mathrm{~nm}$ of tyrosine and other UV chromophores present.

\section{Peptide Synthesis}

The peptide sequence $\mathrm{H}_{2} \mathrm{~N}-\mathrm{Ala}_{4}$-Glu-Ala 3 -Lys-Ala 4 -Tyr-Arg$\mathrm{CONH}_{2}$ was synthesized on Rink amide resin using Fmoc/tBu protection and PyBOP activation on an Advanced Chemtech 348 Omega Multiple Peptide Synthesizer. DMF solvent was degassed with dry nitrogen prior to use. The peptide-resin was then split into smaller portions to which the different $\mathrm{N}$-caps were coupled manually. The peptides were cleaved from the resin by treatment with a solution of TFA/TIS/ $\mathrm{H}_{2} \mathrm{O} /$ DODT (3,6-dioxa-1,8-octanedithiol) (95:2:2:1; Teixeira et al, 2002) for two hours and precipitated by the addition of cold ether. The peptides were purified by semipreparative, reversed-phase HPLC on a Vydac $\mathrm{C}_{18}$ column using linear gradients of eluent A $(0.09 \%$ TFA in $90 \%$ aqueous acetonitrile) and eluent B (0.09\% TFA in water).

\section{1,2,3,4-tetra-O-acetyl- $\beta$-D-glucopyranuronyl-Ala A- $^{-}$ Glu-Ala $-\mathrm{Lys}_{3}-\mathrm{Ala}_{4}-\mathrm{Tyr}-\mathrm{Arg}-\mathrm{CONH}_{2}$}

(1). 1,2,3,4-tetra- $O$-acetyl- $\beta$-D-glucopyranuronic acid (compound $\mathbf{1 0}$, Scheme 1) was prepared from glucuronic acid via the intermediate glucopyranuronic acid acetic anhydride according to established procedures (Tosin and Murphy, 2002). $0.056 \mathrm{~g}$ ( $0.16 \mathrm{mmol}, 3$ equiv) of $\mathbf{1 0}$ was coupled to $100 \mathrm{mg} \mathrm{H}$-(Ala $)_{4}-$ $\mathrm{Glu}(\mathrm{OtBu})-(\mathrm{Ala})_{3}$-Lys(Boc)-(Ala) ${ }_{4}-\mathrm{Tyr}(\mathrm{tBu})-\mathrm{Arg}(\mathrm{Pbf})$-Rink amide $(0.052 \mathrm{mmol})$ in DMF with PyBOP $(0.081 \mathrm{~g}, 0.16 \mathrm{mmol}, 3$ equiv) and DIEA ( $0.027 \mathrm{ml}, 0.16 \mathrm{mmol}, 3$ equiv) for $2 \mathrm{~h}$. Following a negative Kaiser test, the peptide was cleaved, precipitated, and purified by semi-preparative $\operatorname{HPLC}\left(\mathrm{C}_{18}, 0 \rightarrow 100 \% \mathrm{~A}, 30 \mathrm{~min}\right)$ to give a white powder $\left(\mathrm{C}_{73} \mathrm{H}_{114} \mathrm{~N}_{20} \mathrm{O}_{28}, \mathrm{MW}=1719.80 \mathrm{~g} / \mathrm{mol}\right)$.

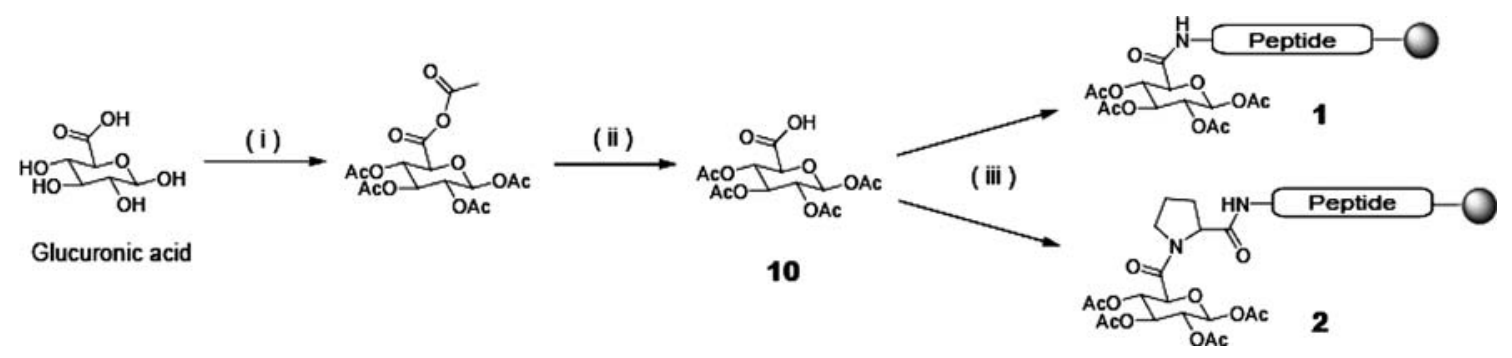

Scheme 1. Synthesis of N-caps 1 and 2. (i) $\mathrm{Ac}_{2} \mathrm{O}$ as solvent, 0.1 eq. $\mathrm{I}_{2}, 2 \mathrm{~h}, 0{ }^{\circ} \mathrm{C}$. Crystallized from DCM/pentane (60\%); (ii) THF/ $\mathrm{H}_{2} \mathrm{O}(2 / 1)$, 3 h, r.t., quantitative; (iii) Resin bound peptide, PyBOP (3equiv), 10 (3 equiv), DIEA (3equiv), DMF, 3 h. 
ESI-MS: $(\mathrm{m} / \mathrm{z}) 860.80[(\mathrm{M}+2 \mathrm{H}) / 2]^{+}, 574.32[(\mathrm{M}+3 \mathrm{H}) / 3]^{+}$. HPLC: $\mathrm{R}_{\mathrm{t}}=6.77\left(\mathrm{C}_{18}, 0 \rightarrow 100 \% \mathrm{~A}\right.$ in $\left.12 \mathrm{~min}\right)$.

\section{1,2,3,4-tetra-O-acetyl- $\beta$-D-glucopyranuronyl-Pro- $\mathrm{Ala}_{4}-\mathrm{Glu}-\mathrm{Ala}_{3}-\mathrm{Lys}_{\mathrm{S}} \mathrm{Ala}_{4}-\mathrm{Tyr}-\mathrm{Arg}-\mathrm{CONH}_{2}$ (2)}

1,2,3,4-tetra- $O$-acetyl- $\beta$-D-glucopyranuronic acid $(0.056 \mathrm{~g}$, $0.16 \mathrm{mmol}, 3$ equiv) was coupled to $100 \mathrm{mg}$ H-Pro-(Ala $)_{4}$ $\mathrm{Glu}(\mathrm{OtBu})-(\mathrm{Ala})_{3}-\mathrm{Lys}(\mathrm{Boc})-(\mathrm{Ala})_{4}-\mathrm{Tyr}(\mathrm{tBu})-\mathrm{Arg}(\mathrm{Pbf})-\mathrm{Rink}$ amide $(0.052 \mathrm{mmol})$ in DMF with PyBOP $(0.081 \mathrm{~g}, 0.16 \mathrm{mmol}, 3$ equiv) and DIEA $(0.027 \mathrm{ml}, 0.16 \mathrm{mmol}, 3$ equiv) for $2 \mathrm{~h}$. A negative chloranil test confirmed that the coupling was complete and the peptide was cleaved, precipitated, and purified by semi-preparative HPLC $\left(\mathrm{C}_{18}, 10 \rightarrow 90 \% \mathrm{~A}, 30 \mathrm{~min}\right)$ to give a white powder. $\left(\mathrm{C}_{78} \mathrm{H}_{121} \mathrm{~N}_{21} \mathrm{O}_{29}, \mathrm{MW}=1816.92 \mathrm{~g} / \mathrm{mol}\right)$. ESI-MS: $(\mathrm{m} / \mathrm{z}) 909.81$ $[(\mathrm{M}+2 \mathrm{H}) / 2]^{+}, 606.79[(\mathrm{M}+3 \mathrm{H}) / 3]^{+}$. HPLC: $\mathrm{R}_{\mathrm{t}}=6.97\left(\mathrm{C}_{18}\right.$, $0 \rightarrow 100 \% \mathrm{~A}$ in $12 \mathrm{~min}$ ).

\section{1,2,3,4,5,6-cyclohexanehexacarboxylic bisanhydride} (12)

1,2,3,4,5,6-cyclohexanehexacarboxylic acid $(1 \mathrm{~g}, 2.87 \mathrm{mmol}$, Scheme 2) was suspended in acetyl chloride and stirred at $120^{\circ} \mathrm{C}$ in a sealed vessel overnight. Filtration and washing with benzene and ether gave an off-white solid $(0.73 \mathrm{~g}, 81 \%)$. ${ }^{1} \mathrm{H}-\mathrm{NMR}$ : $\left(\mathrm{DMSO}_{6}\right), \delta(\mathrm{ppm}) 3.67$ (t, 4H), 3.81 (t, 2H). ${ }^{13} \mathrm{C}-\mathrm{NMR}$ : (DMSO-d ${ }_{6}$ ), $\delta$ (ppm) 171.0 (carboxyl-C), 166.8 (anhydride-C), 37.9, 35.9 (aliphatic-C).

As the product could not be characterized by ESI-MS or HPLC, a small portion was dispersed in ACN and addition of excess cyclohexyl amine precipitated a white solid that was collected by filtration, washed with ether, and identified by ESI-MS as the biscyclohexylamine adduct $\left(\mathrm{C}_{24} \mathrm{H}_{34} \mathrm{~N}_{2} \mathrm{O}_{10}, \mathrm{MW}=510.53 \mathrm{~g} /\right.$ mol). ESI-MS: (m/z) $511.42[\mathrm{M}+\mathrm{H}]^{+}$(biscyclohexylamine adduct).

\section{2,3,4,5,6-cyclohexanepentacarboxyl-Ala $4^{-}$Glu-Ala $_{3}-$ $\mathrm{Lys}_{\mathrm{S}} \mathrm{Ala}_{4}-\mathrm{Tyr}-\mathrm{Arg}-\mathrm{CONH}_{2}$ (3)}

Compound 12 (0.16 g, $0.52 \mathrm{mmol}, 10$ equiv) was added to $100 \mathrm{mg} \quad \mathrm{H}-(\mathrm{Ala})_{4}-\mathrm{Glu}(\mathrm{OtBu})-(\mathrm{Ala})_{3}$-Lys(Boc)-(Ala) $)_{4}-\mathrm{Tyr}(\mathrm{tBu})-$ $\operatorname{Arg}(\mathrm{Pbf})$-Rink amide $(0.052 \mathrm{mmol})$ in DMF with collidine ( $0.090 \mathrm{ml}, 0.52 \mathrm{mmol}, 10$ equiv) and heated to $55^{\circ} \mathrm{C}$ for $1 \mathrm{~h}$. Following a negative Kaiser test, the peptide was cleaved, precipitated, and lyophilized from $1 \mathrm{M}(\mathrm{NH})_{2} \mathrm{CO}_{3}$. Purification by semipreparative HPLC $\left(\mathrm{C}_{18}, 10 \rightarrow 60 \% \mathrm{~A}, 30 \mathrm{~min}\right)$ gave the desired peptide as a white powder $\left(\mathrm{C}_{71} \mathrm{H}_{108} \mathrm{~N}_{20} \mathrm{O}_{29}, \mathrm{MW}=1705.73 \mathrm{~g} /\right.$ mol). ESI-MS: $(\mathrm{m} / \mathrm{z}) 853.85[(\mathrm{M}+2 \mathrm{H}) / 2]^{+}, 596.38[(\mathrm{M}+3 \mathrm{H}) /$ $3]^{+}$. HPLC: $\mathrm{R}_{\mathrm{t}}=5.46\left(\mathrm{C}_{18}, 0 \rightarrow 100 \% \mathrm{~A}\right.$ in $\left.12 \mathrm{~min}\right)$.

\section{2,4,5-benzenetricarboxyl-Ala -Glu-Ala $_{3}-\mathrm{Lys}_{\mathrm{S}} \mathrm{Ala}_{4^{-}}$ Tyr-Arg-CONH$H_{2}$ (4)}

1,2,4,5-benzenetetracarboxylic anhydride $(0.14 \mathrm{~g}, 0.52 \mathrm{mmol}, 10$ equiv) was added to $100 \mathrm{mg} \mathrm{H}$-(Ala) $)_{4}-\mathrm{Glu}(\mathrm{OtBu})-(\mathrm{Ala})_{3}$ - $\mathrm{Lys}(\mathrm{Boc})$ (Ala) $)_{4}-\operatorname{Tyr}(\mathrm{tBu})-\mathrm{Arg}(\mathrm{Pbf})$-Rink amide $(0.052 \mathrm{mmol})$ in DMF with DIEA $(0.11 \mathrm{ml}, 0.52 \mathrm{mmol}, 10$ equiv). The reaction mixture gradually became deep red over the course of $1.5 \mathrm{~h}$ after which a Kaiser test was negative. The peptide was cleaved, precipitated, and lyophilized from $1 \mathrm{M}\left(\mathrm{NH}_{4}\right)_{2} \mathrm{CO}_{3}$. Purification by semi-preparative HPLC $\left(\mathrm{C}_{18}, 10 \rightarrow 60 \% \mathrm{~A}, 30 \mathrm{~min}\right)$ gave the desired peptide as a white powder $\left(\mathrm{C}_{69} \mathrm{H}_{102} \mathrm{~N}_{20} \mathrm{O}_{25}, M W=1611.67 \mathrm{~g} / \mathrm{mol}\right)$. ESI-MS:

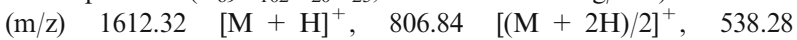
$[(\mathrm{M}+3 \mathrm{H}) / 3]^{+}$. HPLC: $\mathrm{R}_{t}=6.84\left(\mathrm{C}_{18}, 0 \rightarrow 100 \% \mathrm{~A}\right.$ in $\left.12 \mathrm{~min}\right)$.

\section{Cyclic Peptido-Mimetic-Ala ${ }_{4}-G l u-$ Ala $_{3}-L_{y}-$ Ala $_{4}-T y r-$ $\mathrm{Arg}-\mathrm{CONH}_{2}(5)$}

The Cyclic Peptido-Mimetic (CPM) from Hoffmann-La Roche $(0.017 \mathrm{~g}, 0.039 \mathrm{mmol}, 1.5$ equiv) was coupled to $50 \mathrm{mg} \mathrm{H}$ (Ala) $)_{4}$-Glu(OtBu)-(Ala) $)_{3}$-Lys(Boc)-(Ala) ${ }_{4}$ - $\mathrm{Tyr}(\mathrm{tBu})-\mathrm{Arg}(\mathrm{Pbf})$-Rink amide $(0.026 \mathrm{mmol})$ in DMF with PyBOP $(0.021 \mathrm{~g}, 0.039 \mathrm{mmol}$, 1.5 equiv) and DIEA (0.013 ml, $0.078 \mathrm{mmol}, 3.0$ equiv) for $4 \mathrm{~h}$. Following a negative Kaiser test, the peptide was cleaved, precipitated, and purified by semi-preparative HPLC $\left(\mathrm{C}_{18}, 0 \rightarrow 80 \% \mathrm{~A}\right.$, $30 \mathrm{~min})$ to give the desired peptide as a white powder $\left(\mathrm{C}_{83} \mathrm{H}_{121} \mathrm{~N}_{23} \mathrm{O}_{23}, \mathrm{MW}=1808.99 \mathrm{~g} / \mathrm{mol}\right)$. ESI-MS: $(\mathrm{m} / \mathrm{z}) 905.34$ $[(\mathrm{M}+2 \mathrm{H}) / 2]^{+}, 603.82[(\mathrm{M}+3 \mathrm{H}) / 3]^{+}$. HPLC: $\mathrm{R}_{\mathrm{t}}=8.39\left(\mathrm{C}_{18}\right.$, $0 \rightarrow 100 \% \mathrm{~A}$ in $12 \mathrm{~min})$.

\section{$\mathrm{Ac}-\mathrm{Cys}\left(\mathrm{SO}_{3} \mathrm{H}\right)-\mathrm{Ala}_{4}-\mathrm{Glu}-\mathrm{Ala}_{3}-\mathrm{Lys}-\mathrm{Ala}_{4}-\mathrm{Tyr}-\mathrm{Arg}-$ $\mathrm{CONH}_{2}$ (6)}

Fmoc-Cys $\left(\mathrm{SO}_{3} \mathrm{H}\right)-\mathrm{OH} \bullet 2 \mathrm{Na}(0.061 \mathrm{~g}, 0.13 \mathrm{mmol}, 2.5$ equiv $)$ was coupled to $100 \mathrm{mg} \mathrm{H}$-(Ala) ${ }_{4}$-Glu(OtBu)-(Ala) $)_{3}$-Lys(Boc)(Ala) $)_{4}-\operatorname{Tyr}(\mathrm{tBu})-\operatorname{Arg}(\mathrm{Pbf})$-Rink amide $(0.052 \mathrm{mmol})$ in DMF with PyBOP (0.068 g, $0.13 \mathrm{mmol}, 2.5$ equiv) and DIEA $(0.046 \mathrm{ml}$, $0.26 \mathrm{mmol}, 5$ equiv) for $1 \mathrm{~h}$ and checked by Kaiser test. Following Fmoc deprotection and acetylation, the peptide was cleaved, precipitated, and purified by semi-preparative $\operatorname{HPLC}\left(\mathrm{C}_{18}, 10 \rightarrow\right.$

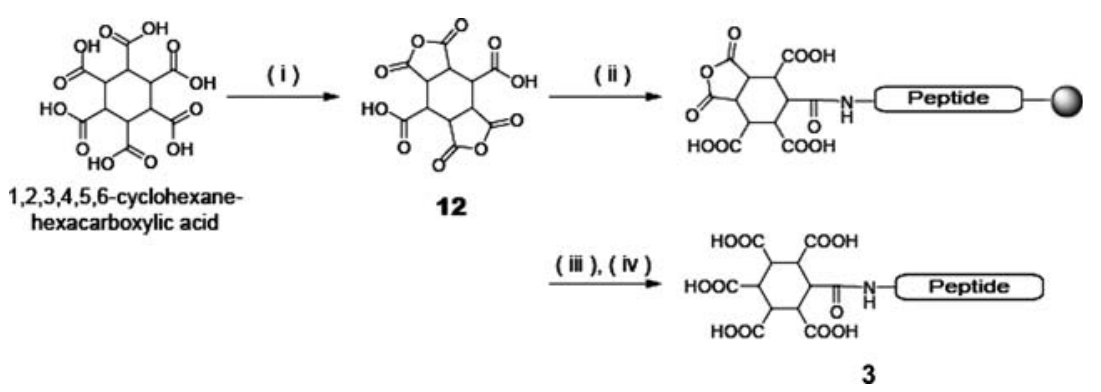

Scheme 2. Synthesis of N-cap 3; (i) acetyl chloride, $120^{\circ} \mathrm{C}, 18 \mathrm{~h}$, quantitative; (ii) Resin bound peptide, 12 (5 equiv), collidine (10 equiv), DMF, 1 h; (iii) TFA/TIS/ $\mathrm{H}_{2} \mathrm{O} /$ DODT (95:2:2:1); (iv) Lyophilize from 1.0M $\left(\mathrm{NH}_{4}\right)_{2} \mathrm{CO}_{3}$. 


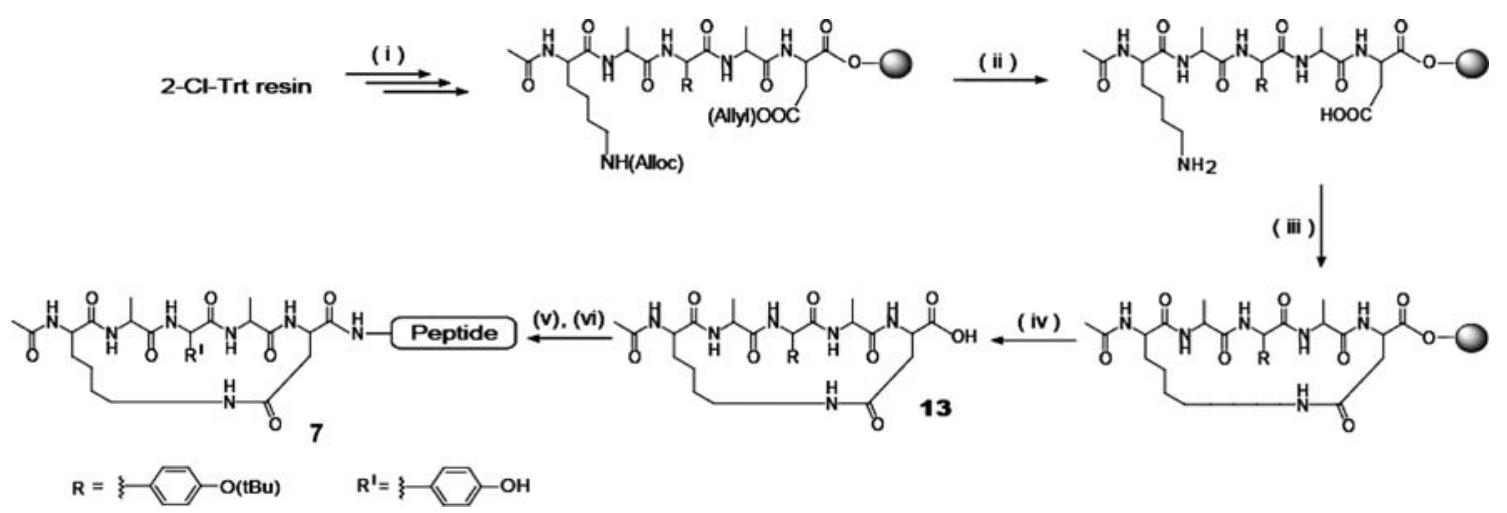

Scheme 3. Synthesis of $\mathrm{N}$-cap 7; (i) Fmoc/tBu SPPS; (ii) $\mathrm{Pd}\left(\mathrm{PPh}_{3}\right)_{4}$ (0.5 equiv), $\mathrm{PhSiH}_{3}$ (10 eqiv), TIS (10 equiv), $\mathrm{CHCl}_{3}, \mathrm{~N}_{2}, 2$ h; (iii) $\mathrm{PyBOP}$ (1.5 equiv), DIEA (3equiv), NMP, 4 h; (iv) DCM/TFE/AcOH (70/20/10), 2 h; (v) Resin bound peptide, PyBOP (2.5 equiv), 13 (2.5 equiv), DIEA (2.5 equiv), DMF, 2 h; (vi) TFA/TIS/ $\mathrm{H}_{2} \mathrm{O} / \mathrm{DODT}$ (95:2:2:1), $2 \mathrm{~h}$.

$60 \% \mathrm{~A}, 30 \mathrm{~min})$ to give the desired peptide as a white powder $\left(\mathrm{C}_{64} \mathrm{H}_{105} \mathrm{~N}_{21} \mathrm{O}_{23} \mathrm{~S}_{2}, \quad \mathrm{MW}=1600.78 \mathrm{~g} / \mathrm{mol}\right) . \quad$ ESI-MS: $\quad(\mathrm{m} / \mathrm{z})$ $1601.66[\mathrm{M}+\mathrm{H}]^{+}, 800.83[(\mathrm{M}+2 \mathrm{H}) / 2]^{+}, 534.79[(\mathrm{M}+3 \mathrm{H}) /$ $3]^{+}$. HPLC: $\mathrm{R}_{t}=6.62\left(\mathrm{C}_{18}, 0 \rightarrow 100 \% \mathrm{~A}\right.$ in $\left.12 \mathrm{~min}\right)$.

\section{Ac-(cyclo-1-5)-Lys-Ala-Tyr (tBu)-Ala-Asp-OH (13)}

Peptide 13 (Scheme 3) was prepared by manual stepwise SPPS on trityl chloride resin $(1.5 \mathrm{mmol} / \mathrm{g}, 1 \mathrm{~g}, 1.5 \mathrm{mmol})$. The coupling of the first residue was effected by adding 1.2 equiv amino acid with DIEA (4 equiv relative to amino acid) to the resin in DCM while all other couplings were performed using PyBOP/DIEA activation.

After the assembly of the linear peptide was complete, the aspartic acid and lysine side chains were deprotected by treating the peptide-resin with $\mathrm{Pd}\left(\mathrm{PPh}_{3}\right)_{4}(0.083 \mathrm{~g}, 0.075 \mathrm{mmol}, 0.05$ equiv $)$ and $\mathrm{PhSiH}_{3}\left(0.9 \mathrm{ml}, 7.5 \mathrm{mmol}, 5\right.$ equiv) in $\mathrm{CHCl}_{3}$ under argon for $2 \mathrm{~h}$. The resin was then washed with DCM, DMF, and $0.5 \%$ diethyldithiocarbamate in DMF. Cyclization was effected on resin using PyBOP ( $1.17 \mathrm{~g}, 2.25 \mathrm{mmol}, 1.5$ equiv) and DIEA $(0.51 \mathrm{ml}$, $3.0 \mathrm{mmol}, 2$ equiv) in NMP for $4 \mathrm{~h}$ after which a Kaiser test was negative. Cleavage was achieved with a mixture of $\mathrm{AcOH} / \mathrm{TFE} /$ DCM 10:20:70, $2 \times 1 \mathrm{~h}$. Removal of solvent in vacuo and purification by semi-preparative HPLC $\left(\mathrm{C}_{18}, 0 \rightarrow 75 \% \mathrm{~A}, 30 \mathrm{~min}\right)$ yielded the desired peptide $\left(\mathrm{C}_{31} \mathrm{H}_{46} \mathrm{~N}_{6} \mathrm{O}_{9}, \mathrm{MW}=646.73 \mathrm{~g} / \mathrm{mol}\right)$. ESI-MS: $(\mathrm{m} / \mathrm{z}) 647.64[\mathrm{M}+\mathrm{H}]^{+}$. HPLC: $\mathrm{R}_{t}=4.57\left(\mathrm{C}_{18}, 0 \rightarrow\right.$ $100 \% \mathrm{~A}$ in $10 \mathrm{~min})$.

Ac-(cyclo-1-5)-Lys-Ala-Tyr-Ala-Asp-Ala $4^{-}$Glu- $^{-}$Ila $_{3^{-}}$ Lys-Ala 4 -Tyr-Arg-CONH $\mathrm{CH}_{2}$ (7)

Ac-[(cyclo-1-5)-Lys-Ala-Tyr(tBu)-Ala-Asp]-OH 13 (0.084 g, $0.13 \mathrm{mmol}, 2.5$ equiv) was coupled to $100 \mathrm{mg} \mathrm{H}$-(Ala) $)_{4}$-Glu-(Ala $)_{3-}$ Lys-(Ala) $)_{4}$-Tyr-Arg-Rink amide $(0.052 \mathrm{mmol})$ in DMF with PyBOP $(0.068 \mathrm{~g}, 0.13 \mathrm{mmol}, 2.5$ equiv) and DIEA $(0.023 \mathrm{ml}$, $0.13 \mathrm{mmol}, 2.5$ equiv) for $2 \mathrm{~h}$ and checked by Kaiser test. The peptide was cleaved, precipitated, and purified by semi-preparative $\operatorname{HPLC}\left(\mathrm{C}_{18}, 0 \rightarrow 80 \% \mathrm{~A}, 30 \mathrm{~min}\right)$ to give the desired peptide as a white powder $\left(\mathrm{C}_{86} \mathrm{H}_{134} \mathrm{~N}_{26} \mathrm{O}_{26}, \mathrm{MW}=1948.14 \mathrm{~g} / \mathrm{mol}\right)$. ESI-MS: $(\mathrm{m} / \mathrm{z}) 974.86[(\mathrm{M}+2 \mathrm{H}) / 2]^{+}, 650.32[(\mathrm{M}+3 \mathrm{H}) / 3]^{+}$. HPLC: $\mathrm{R}_{t}=7.08\left(\mathrm{C}_{18}, 0 \rightarrow 100 \% \mathrm{~A}\right.$ in $\left.12 \mathrm{~min}\right)$.

\section{RESULTS AND DISCUSSION}

The choice of peptide sequence for the evaluation of $\mathrm{N}$-cap efficiency is critical as earlier studies report very wide ranges of increases in helicity, with larger increases typically reported for sequences that were already weakly helical or shorter in length. Therefore, for the direct comparison of the helix inducing efficiency of different $\mathrm{N}$-caps, a previously designed system, the alanine-rich model peptide $\mathrm{H}_{2} \mathrm{~N}_{-} \mathrm{Ala}_{4}-$ Glu-Ala 3 -Lys-Ala 4 -Tyr-Arg-CONH ${ }_{2}$ was chosen (Forood et al., 1994). The arginine serves as the Ccapping residue, the tyrosine at position 14 permits UV quantitation, and glutamic acid and lysine residues at positions 5 and 9 respectively are ideally located to form an intrahelical salt bridge and thus, increase overall solubility.

The design of possible $\mathrm{N}$-caps was based on two primary principles. Firstly, the N-cap should possess numerous hydrogen bonding acceptors including a carboxyl or anhydride group suitable for the attachment to the $\mathrm{N}$-terminus of a peptide and, secondly, it should be straightforward to synthesize.

Figure 1 displays the $\mathrm{N}$-cap candidates in their peptide-conjugated form that were investigated, none of which have been previously explored as potential $\mathrm{N}$-caps except for compound $\mathbf{5}^{4}$ (Müller et al., 1993). Sugars offer the potential for readily available scaffolds that can present five or more hydrogen bond acceptors upon peracetylation. While there are numerous publications on the effects of attached

${ }^{4}$ Compound 5 was a generous gift from Prof. Klaus Müller, Hoffmann-La Roche, Basel. 


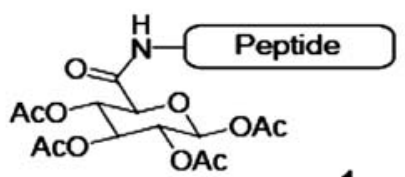

1

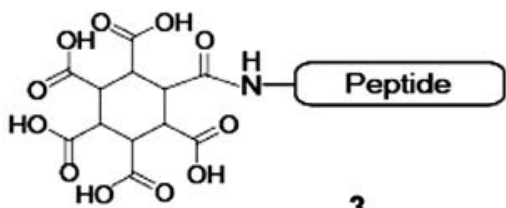

3
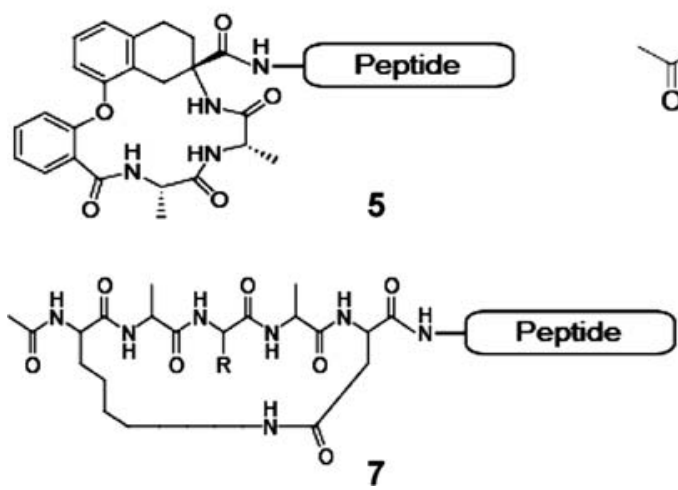

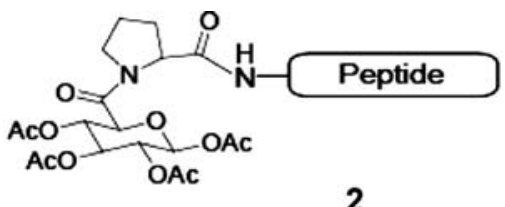<smiles>CCCCCCCCCCCCCNC(=O)c1cc(C(=O)O)c(C(=O)O)cc1C(=O)O</smiles>

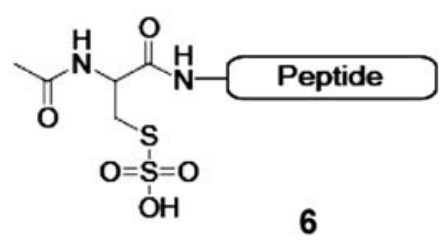

Fig. 1. N-cap candidates in their peptide-conjugated form.

sugars on peptide conformation (Bosques et al., 2004), (Otvos and Cudic, 2003), the use of sugarderived molecules as possible $\mathrm{N}$-caps remains unexplored. For example, peracetylation of $\beta$-Dglucuronic acid with iodine catalyst followed by liberation of the carboxyl group yielded glucopyranuronic acid (compound 10, Scheme 1) that was soluble in organic solvents (Tosin and Murphy, 2002). This product was readily coupled to the model peptide by standard solid-phase peptide synthesis (SPPS) to give N-capped peptide 1 (Scheme 1). Based on the fact that proline residues are found to support helix formation when found near the N-termini (Pal et al., 2003) for the $\mathrm{N}$-capped peptide $\mathbf{2}$ the peptide sequence was further extended by one proline residue on solid phase prior to coupling the sugar derivative 10. N-caps 3 and 4 are derived from cyclic polycarboxylic acids that are subsequently converted to the corresponding acid anhydrides. The anhydrides are reacted with the $\mathrm{N}$-terminus of the peptide. After completion of the coupling, the remaining anhydrides are hydrolysed to the carboxyl groups during the cleavage of the peptide from the resin as depicted in Scheme 2. The peptide was further treated with base to drive the hydrolysis to completion, ideally with ammonium carbonate as it is removed during lyophilization. The resulting $\mathrm{N}$-caps bear several carboxyl groups, each of which can potentially engage in hydrogen bonding with two peptidic amide groups. In more detail, the anhydride of $\mathrm{N}$-cap $\mathbf{3}$ is obtained by heating 1,2,3,4,5,6-cyclohexanehexacarboxylic acid in acetyl chloride at $120^{\circ} \mathrm{C}$ in a sealed vessel overnight (Betnev et al., 1999). The anhydride of N-cap 4, 1,2,4,5-benzene tetracarboxylic anhydride, is commercially available. The above acylation strategy was successfully used to introduce $\mathrm{N}$-caps $\mathbf{3}$ and 4. In a study of $\mathrm{N}$-capping groups containing a sulphur atom in various oxidation states, the sulfonic acid moiety turned out to be the most $\alpha$-helix stabilizing N-cap (Forood et al., 1994). This unit was introduced at the $\mathrm{N}$-terminus of the peptide by coupling of S-trityl-3-mercaptopropionic acid. After cleavage of the peptide from the resin and purification, the thiol group was oxidized with performic acid to give the sulfonic acid. In contrast, for the synthesis of $\mathrm{N}$-capped peptide $\mathbf{6}$, the coupling of the disodium salt of Fmoc-Cys $\left(\mathrm{SO}_{3} \mathrm{H}\right)-\mathrm{OH}$, which is commercially available from Bachem (Bubendorf, Switzerland), 
provides a straightforward means for introducing a sulfonic acid moiety to a peptide by standard PyBOP activated coupling methods. After completion of the reaction, the Fmoc protection was removed and the terminal $\mathrm{NH}_{2}$-group acetylated. $\mathrm{N}$-cap 7 consists of a pentapeptide containing aspartic acid and lysine residues at positions i and i +4 respectively. Orthogonal allyl-based protection of the Lys and Asp side chains allows for selective Pd-catalysed deprotection and subsequent on-resin cyclization via a lactam bridge (Scheme 3). This effectively constrains the residues into an enforced $\alpha$-helical turn and, when incorporated into a larger peptide, can greatly increase the overall helicity (Felix et al., 1988). The Fairlie group recently reported a method of synthesizing protected lactam-bridged pentapeptide fragments that could be used as building blocks in SPPS (Shepherd et al., 2004). The peptide is constructed and cyclized on a highly acid labile support. Cleavage under mildly acidic conditions results in a fully protected peptide fragment with a free acid at the C-terminus, suitable for further coupling to a resin bound peptide by standard SPPS methodologies. Table I summarizes the results obtained with the series of N-caps and Fig. 2 shows some of the corresponding $\mathrm{CD}$ spectra of the N-capped peptides. The peptide sequence lacking the N-cap $(\mathrm{N}$-cap $=\mathrm{H})$ is only weakly helical $(18 \%)$ while acetylation of the $\mathrm{N}$-terminus leads to an increase in helicity of up to $32 \%$ as reported in literature (Forood et al., 1994). However, all N-caps listed in Table 1 containing multiple hydrogen bond acceptors induce significant increases in the overall helicity compared

Table I. Summary of helix contents of N-cap-Ala 4 -Glu-Ala 3 -Lys$\mathrm{Ala}_{4}$-Tyr-Arg-CONH${ }_{2}$. Percent helicity is calculated as 100 $\left([\theta]_{222} /{ }^{\max }[\theta]_{222}\right)$, where $[\theta]_{222}$ is the mean residue ellipticity value at $222 \mathrm{~nm}$ and ${ }^{\max }[\theta]_{222}$ is the theoretical maximum possible value given by the formula ${ }^{\text {max}}[\theta]_{222}=-40,000[1-(2.5 / \mathrm{n})]$ (Scholtz et al., 1991). The variable $\mathrm{n}$ refers to the number of amino acid residues in the peptide being measured and the value $-40,000 \mathrm{deg} \cdot \mathrm{cm}^{2} \cdot \mathrm{dmol}^{-1}$ is the value used for the infinite helix $(n=\infty)$ (Chen et al., 1974). Percent helicity was independent of peptide concentration in the range of $5-100 \mu \mathrm{M}$ (data not shown)

\begin{tabular}{lcll}
\hline $\begin{array}{l}\text { N-capped } \\
\text { peptide }\end{array}$ & $\begin{array}{c}-[\theta]_{222} \\
\left(\mathrm{deg} \cdot \mathrm{cm}^{2} \cdot \mathrm{dmol}^{-1}\right)\end{array}$ & $\begin{array}{c}\text { No. of } \\
\text { residues (n) }\end{array}$ & $\%$ helicity \\
\hline No N-cap & 6,100 & 15 & 18 \\
1 & 18,100 & 15 & 54 \\
2 & 15,100 & 16 & 45 \\
3 & 20,000 & 15 & 62 \\
4 & 23,300 & 15 & 70 \\
5 & 29,700 & 15 & 89 \\
6 & 16,500 & 16 & 49 \\
7 & 30,100 & 20 & 86 \\
\hline
\end{tabular}

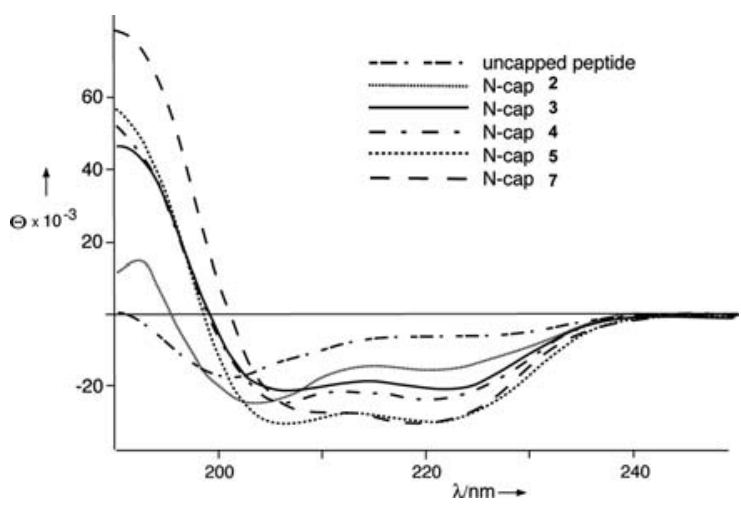

Fig. 2. CD curves of peptides N-cap-Ala 4 -Glu-Ala 3 -Lys-Ala 4 -TyrArg- $\mathrm{NH}_{2}$ with selected $\mathrm{N}$-caps at $1.0 \times 10^{-5} \mathrm{M}$ in $\mathrm{pH} 7$ phosphate buffer at $0{ }^{\circ} \mathrm{C}$.

to the uncapped or acetylated peptide.The least efficient are the sugar based $\mathbf{N}$-caps $\mathbf{1}$ and $\mathbf{2}$. It is possible that the acetyl groups do not adopt a low energy conformation to serve as $\mathrm{H}$-bond acceptors being crucial for a helix stabilizing potential. However, given the large number of different sugars available exposing alternative orientations of the acetyl groups in space, the use of sugar based molecules as N-caps might best be explored by combinatorial techniques (Le et al., 2003). From the perspective of helix inducing power versus ease of synthesis, N-cap 4 seems the best choice. Two steps, i.e. acylation of the peptide with 1,2,4,5-benzene tetracarboxylic anhydride and following hydrolysis of the remaining anhydride, lead to an increase in peptide helicity from $17 \%$ to $70 \%$. It is important to note, that even though both $\mathrm{N}$-caps $\mathbf{3}$ and $\mathbf{4}$ contain multiple, ionisable carboxyl groups, their influence on the helicity of the model peptide was found to be $\mathrm{pH}$-independent in the range of $2-10$. The cyclic pentapeptide $\mathrm{N}$-cap 7 as well as the tetrahydronaphthalene based $\mathrm{N}$-cap $\mathbf{5}$ proved to be the most efficient helix nucleators (86\% and $89 \%$ helicity). While the observed $[\theta]_{222}$ values of both molecules are very close, the course of the CD spetrum of N-cap 7 shows additional characteristics that indicate greater helicity (Fig. 2). Firstly, the zero transition is at $201 \mathrm{~nm}$, consistent with literature values for helix standards (Fasman, 1996). Secondly, the $[\theta]_{222} /[\theta]_{208}$ ratio is equal to 1.2 , a value close to that recently proposed by the Kemp group (ratio of 1.3) for alanine-rich peptides adopting a complete helical conformation (Heitmann et al., 2005), especially at lower temperatures (Job et al., 2006). N-cap 5, however, also produced a high degree of helicity (89\%) when the contribution of the amino acid residues forming the $\mathrm{N}$-cap were neglected in the 
a)

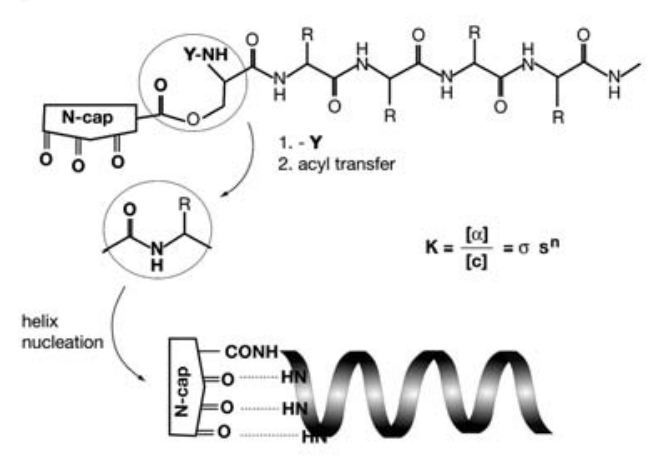

b)

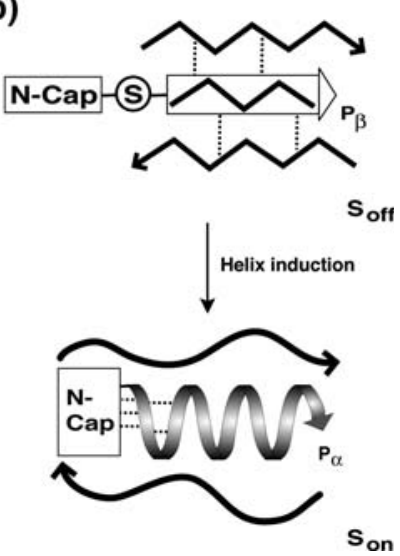

Fig. 3. (a) Concept of Switch-Peptides (Mutter et al., 2004). The impact of the N-cap is triggered in situ by chemical or enzymatic removal of $\mathrm{Y}$ resulting in $\mathrm{O} / \mathrm{N}$ - acyl migration (Soff to Son state) paralleled by the onset of the helix-inducing effect. (b) The N-cap containing switchpeptide intercalates into a $\beta$-sheet fibril forming host peptide (Soff state). By triggering $\mathrm{O} / \mathrm{N}$ acyl migration, the $\beta$-sheet of the switch-peptide transforms to an $\alpha$-helical structure (Son state), thus destabilizing or disrupting the $\beta$ sheet assembly.

calculation of the helix content. Though it is very effective at nucleating helical structure, the synthesis of this scaffold is very complex and involves more than forty steps (Müller et al., 1993).

\section{OUTLOOK}

The present investigation represents a first, systematic comparison of a series of readily accessible $\mathrm{N}$-caps that differ widely in the number, orientation, and type of hydrogen bond acceptors, some scaffolds generating an increase in helicity up to 4-fold with respect to the uncapped peptides. In general, the overall induced ellipticity values of the different $\mathrm{N}$-caps presented do not vary greatly, but the data obtained clearly demonstrate the potency of the helix inducing effect of $\mathrm{N}$-caps in comparison with the uncapped peptides. The scope of the present paper was not the design and/or optimisation of ideal Ncap candidates rather a first evaluation of synthetically easily accessible molecules with a pronounced helix inducing power. From this point of view the cyclic peptide $\mathrm{N}$-cap 7 appears as the most promising candidate due to its potential structural variability and ease of synthesis even amenable to combinatorial approaches.

Continuing advances in the rational design and optimisation of helix inducing $\mathrm{N}$ - and C-caps may eventually obviate the need to alter a peptide's core sequence with nonnative residues or peptidomimetics in order to increase its overall helicity. Most notably,
$\mathrm{N}$-caps may play a crucial role in reversing aggregated $\beta$-sheet assemblies of peptides to helical states as relevant in fibrillogenesis as origin of degenerative diseases. Preliminary studies for the use of $\mathrm{N}$-caps to transform $\beta$-sheet- and fibril-forming $\mathrm{A} \beta$-derived peptides to helical structures in situ applying the concept of switch-peptides (Fig. 3, Mutter et al., 2004) confirm the potential of this approach for therapeutic applications (Mimna et al., 2006).

\section{ACKNOWLEDGMENTS}

This work was supported by the Swiss National Science Foundation and Debiopharm S.A., Lausanne.

\section{REFERENCES}

Aurora, R. and Rose, G.D.: 1998, Protein Sci. 7, 21-38.

Barazza, A., Wittelsberger, A., Fiori, N., et al.: 2005, J. Peptide Res. 65, 23-35.

Barlow, D. J. and Thornton, J. M.: 1988, J. Mol. Biol. 201, 601619.

Bayer, E. and Mutter, M.: 1972, Nature 237, 265-268.

Beck-Sickinger, A. G. and Jung, G.: 1995, Biopolymers 37, 123142.

Bernheimer, A. W. and Rudy, B.: 1986, Biochim. Biophys. Acta 864, 123-141.

Betnev, A. F., Obukhova, T. A., Budanov, N. A., Kolpashchikova, I. S. and Betnev, S. A.: 1999, Russ. J. Org. Chem. 35, 519-521.

Bodanszky, M.: 1984, Principles of Peptide Synthesis, SpringerVerlag Berlin, Heidelberg, New York, Tokyo. 
Bosques, C. J., Tschampel, S. M., Woods, R. J. and Imperiali, B.: 2004, J. Am. Chem. Soc. 126, 8421-8425.

Chen, Y. H., Yang, J. T. and Chau, K. H.: 1974, Biochemistry 13, 3350-3359.

Ellenberger, T. E., Brandl, C. J., Struhl, K. and Harrison, S. C.: 1992, Cell 71, 1223-1237.

Fasman, G. D.: 1996, Circular Dichroism and the Conformational Analysis of Biomolecules, Plenum Press, New York.

Felix, A. M., Heimer, E. P., Wang, C. T. and , : 1988, Int. J. Pep. Prot. Res. 32, 441-454.

Forood, B., Reddy, H. K. and Nambiar, K. P.: 1994, J. Am. Chem. Soc. 116, 6935-6936.

Heitmann, B., Job, G. E., Kennedy, R. J., Walker, S. M. and Kemp, D. S.: 2005, J. Am. Chem. Soc. 127, 1690-1704.

Job, G. E., Kennedy, R. J., Heitmann, B., Miller, J. S., Walker, S. M. and Kemp, D. S.: 2006, J. Am. Chem. Soc. 128, 8227-8233.

Le, G. T., Abbenante, G., Becker, , Gratwohl, M., Halliday, J., Tometzki, G., Zuegg, J. and Meutermans, W.: 2003, Drug Disc. Today 8, 701-709.

Maison, W., Arce, E., Renold, P., Kennedy, R. J. and Kemp, D. S.: 2001, J. Am. Chem. Soc. 123, 10245-10254.

Merrifield, R. B.: 1963, J. Am. Chem. Soc. 85, 2149-2154.

Mimna, R., Camus, M.-S., Schmid, A., Tuchscherer, G., Lashuel. H. and Mutter, M.: 2006, Angew. Chem. Int. Ed., in press.

Motta, A., Morelli, M. A. C., Goud, N. and Temussi, P. A.: 1989, Biochemistry 28, 7996-8002.
Mutter, M. and Tuchscherer, G.: 2000, Chimia 54, 552-557.

Müller, K., Obrecht, D., Knierzinger, A., Stankovic, C., Spiegler, C., Bannwarth, W., Trzeciak, A., Englert, G., Labhard, A.M.and Schönholzer, P.: 1993, in B. Testa, E. Kyburz, W. Fuhrer and R. Giger (eds.), Perspectives in Medicinal Chemistry. Verlag Helvetica Chimica Acta, Basel, pp. 513-533.

Mutter, M., Chandravarkar, A., Boyat, C., Lopez, J., Dos Santos, , Mandal, B., Mimna, R., Murat, K., Patiny, L., Saucède, P. and Tuchscherer, G.: 2004, Chem. Int. Ed. 43, 4172-4178.

Otvos, L. Jr. and Cudic, M.: 2003, Mini Revs. in Med. Chem. 3, 703-711.

Pal, L., Chakrabarti, P. and Basu, G.: 2003, J. Mol. Biol. 326, $273-$ 291.

Scholtz, J. M., Qian, H., York, E. J., Stewart, J. M. and Baldwin, R. L.: 1991, Biopolymers 31, 1463-1470.

Shepherd, N. E., Abbenante, G. and Fairlie, D. P.: 2004, Angew. Chem. Int. Ed. 43, 2687-2690.

Teixeira, A., Benckhuijsen, W. E., de Koning, P. E., Valentijn, A. R. P. M. and Drijfhout, J. W.: 2002, Prot. \& Pept. Lett. 9, 379-385.

Tosin, M. and Murphy, P. V.: 2002, Org. Lett. 4, 3675-3678.

Tuchscherer, G., Lehmann, C. and Mathieu, M.: 1998, Angew. Chem. Int. Ed. 37, 2990-2993.

Stewart, J. M. and Young, J. D.: 1984, Solid Phase Peptide Synthesis, Pierce Chemical Company, Rockford, IL. 